\title{
In situ measurement of the biogeochemical properties of Southern Ocean mesoscale eddies in the Southwest Indian Ocean, April 2014
}

\author{
S. de Villiers, K. Siswana, and K. Vena \\ Oceans and Coastal Research, Department of Environmental Affairs, Cape Town, South Africa
}

Correspondence to: S. de Villiers (steph.devilliers@gmail.com)

Received: 3 September 2015 - Published in Earth Syst. Sci. Data Discuss.: 2 October 2015

Revised: 30 November 2015 - Accepted: 30 November 2015 - Published: 10 December 2015

\begin{abstract}
Several open-ocean mesoscale features - a "young" warm-core (anti-cyclonic) eddy at $52^{\circ} \mathrm{S}$, an "older" warm-core eddy at $57.5^{\circ} \mathrm{S}$ and an adjacent cold-core (cyclonic) eddy at $56^{\circ} \mathrm{S}$ - were surveyed during a R/V S.A. Agulhas II cruise in April 2014. The main aim of the survey was to obtain hydrographical and biogeochemical profile data for contrasting open-ocean eddies in the Southern Ocean, which will be suitable for comparative study and modelling of their heat, salt and nutrient characteristics, and the changes that occur in these properties as warm-core eddies migrate from the polar front southwards. The major result is that the older warm-core eddy at $57.5^{\circ} \mathrm{S}$ is, at its core, $2.7^{\circ} \mathrm{C}$ colder than a younger eddy at $52^{\circ} \mathrm{S}$, while its dissolved silicate levels are almost $500 \%$ higher and accompanied by chlorophyll $a$ levels that are more than $200 \%$ higher than that in the younger eddy. A total of 18 CTD stations were occupied in a sector south of the Southwest Indian Ridge, along three transects crossing several mesoscale features identified from satellite altimetry data prior to the cruise. The CTD data, as well as chlorophyll $a$ and dissolved nutrient data (for $\mathrm{NO}_{3}^{-}, \mathrm{NO}_{2}^{-}, \mathrm{PO}_{4}^{3-}$ and $\mathrm{SiO}_{2}$ ), have been processed, quality controlled and made available via the PANGAEA Data Archiving and Publication database at doi:10.1594/PANGAEA.848875.
\end{abstract}

\section{Introduction}

The circulation and thermohaline structure of the Southern Ocean is of critical importance to global exchanges of heat, freshwater and biogeochemical constituents such as nutrients and $\mathrm{CO}_{2}$. A detailed understanding of the role of mesoscale eddy transport in these processes is still lacking. It has only fairly recently been established that mesoscale eddies contain most of the kinetic energy of ocean circulation (Fu et al., 2010; Ferrari and Wunsch, 2009) and that the global zonal eddy volume transport is comparable in magnitude to that of the large-scale wind- and thermohaline-driven circulation (Zhang et al., 2014). It is estimated that in the open ocean most of the vertical transport of biogeochemical properties, such as nutrients, takes place at the sub-mesoscale and is associated with eddies (Klein and Lapeyre, 2009; McGillicuddy Jr. et al., 2007; Lévy et al., 2001). At the global scale, areas of enhanced eddy kinetic energy usually also ex- hibit elevated levels of marine primary productivity (Chelton et al., 2011; Falkowski et al., 1991; Siegel et al., 2011). However, our understanding of the global significance of coincident large-scale patterns of enhanced open-ocean productivity and mesoscale activity, as well as the importance of eddyinduced nutrient transport, is still in its infancy.

Progress in this field, including the incorporation of biogeochemical cycles into eddy-resolving general circulation models, is severely limited by scarce in situ data, collected with the specific aim of improving our understanding of the physical and biogeochemical processes associated with mesoscale features such as eddies (Joyce et al., 1981; Mahadevan and Archer, 2010; Ansorge et al., 2010; Lehahn et al., 2011; Stramma et al., 2013; Chen et al., 2015). This scarcity of in situ data is particularly pronounced in the Southern Ocean. Despite the significance of the Southern Ocean to ocean-atmosphere $\mathrm{CO}_{2}$ exchange and global climate, and the important role of ocean eddies to these pro- 


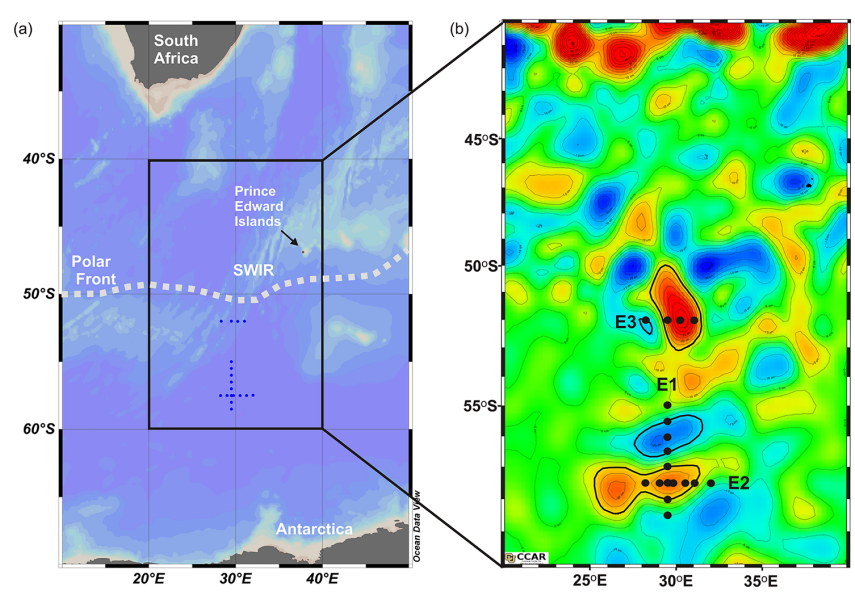

Figure 1. (a) Seafloor bathymetry in the southwestern Indian Ocean sector of the Southern Ocean to indicate the position of the Southwest Indian Ridge (SWIR); shown in grey is the average position of the polar front (adapted from Dong et al., 2006). (b) The CTD station locations along transect lines E1 to E3 are shown as black dots superimposed upon a satellite altimetry map; red indicates positive SSHAs and blue indicates negative SSHAs. SSHA contour intervals are $5 \mathrm{~cm}$, and the $-10 \mathrm{~cm}$ and $+10 \mathrm{~cm}$ contour lines that the transect lines cross are highlighted with solid black lines.

cesses (Frenger et al., 2013; Sheen et al., 2014; Morrow et al., 1994), it remains a remote, hostile and under-sampled ocean environment.

The objective of this paper is to present an overview of in situ data that had been collected in the southern hemispheric autumn, across a number of distinct mesoscale features in the southwestern Indian sector of the Southern Ocean (Fig. 1), and to make this data set available to the scientific community. The interaction of the Antarctic Circumpolar Current with the shallow topographic features of the Southwest Indian Ocean Ridge plays an important role in the generation of open-ocean eddies just south of the polar front (Gouretski and Danilov, 1994; Pollard and Read, 2001; Durgadoo et al., 2011; Ansorge et al., 2015). The subsequent movement of these eddies in a southerly direction, into the Southern Ocean proper, represents an ideal natural laboratory for the in situ observation and study of the eddy transport of heat, salt and chemicals across strong frontal zones in the Southern Ocean. To date, detailed studies of the chemical characteristics of such eddies and the evolution of these properties over time and distance have not been carried out. This represents an important knowledge gap, particularly with regards to understanding Southern Ocean nutrient transport processes and carbon cycling.

\section{Sampling survey design}

The survey cruise was conducted from 2 April to 6 May 2014 (EXPOCODE 91AH20140402), the austral autumn, as part of the Department of Environmental Affairs' 2014 Marion

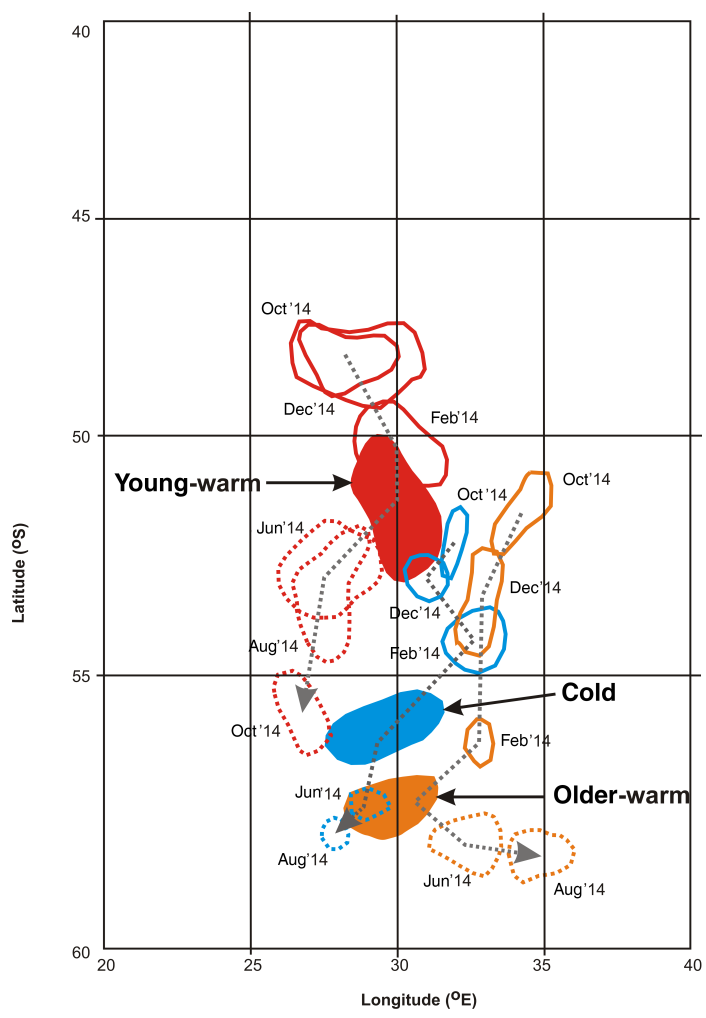

Figure 2. Eddy migration tracks, as inferred from SSHA archive data. Solid red, blue and orange areas respectively reflect the area inside the $10 \mathrm{~cm}$ SSHA contour for the young, warm-core, coldcore and the older, warm-core eddies at the time of sampling. Solid red, blue and orange lines, similarly, indicate the position of the eddies (and the extent of the eddy within the $10 \mathrm{~cm}$ SSHA contour) prior to sampling, at 2-month intervals, as indicated by the labels. Broken red, blue and orange lines indicate the position of the eddies subsequent to sampling, again at 2-month intervals. Black arrows are used to highlight the southerly migration of the eddies.

Relief Voyage 011 on the M/V S.A. Agulhas II to its base in the subantarctic Prince Edward Islands (Fig. 1a). The M/V S.A. Agulhas II is a relatively new (commissioned in 2012) polar research and supply vessel and is equipped with a moon pool that can be used as a CTD launch area, even in the event of severe weather conditions.

Several months prior to the ship survey, evaluation of satellite altimetry sea surface height anomaly (SSHA) data was initiated to identify and track the position of eddies suitable for study (Fig. 2). Composite SSHA satellite altimetry data, representing the sampling period, were obtained from the online data viewer of the Colorado Center for Astrodynamics Research (CCAR) (http://eddy.colorado.edu/ccar/ data_viewer/index) (Fig. 1b). The global Historical Gridded SSH data viewer was used, which is typically a composite of \pm 10 days of Topex/Poseidon, Jason-a and Jason-2/OSTM data. 
(a)

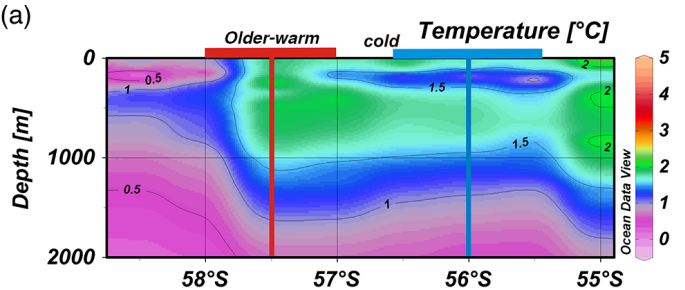

(b)

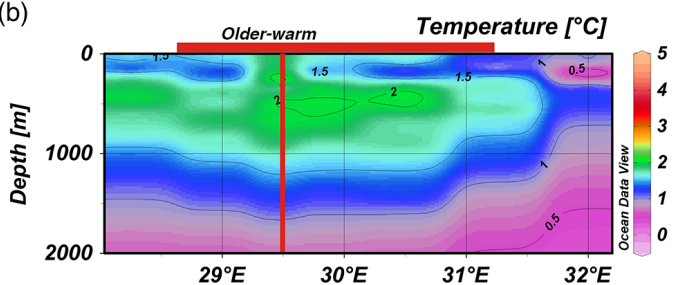

(c)

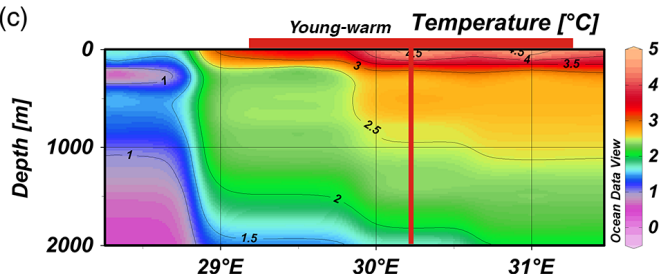

(d)

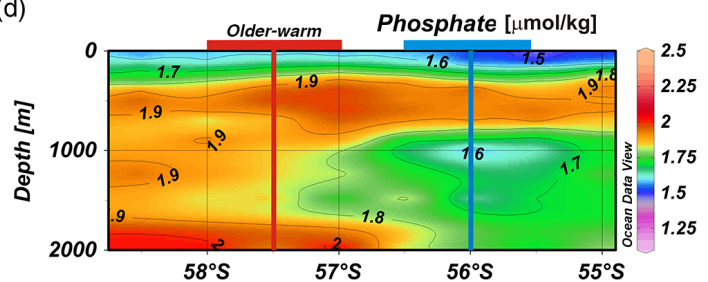

(e)

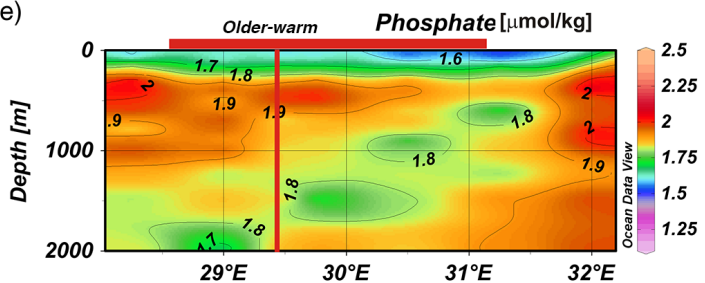

(f)

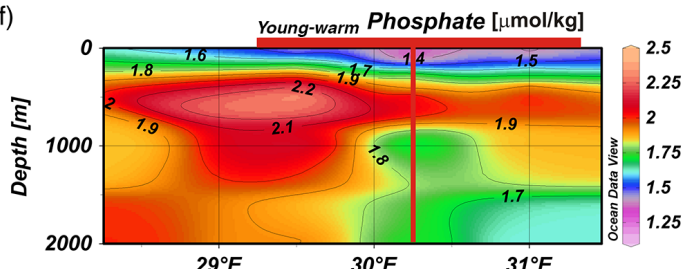

Figure 3. Temperature and dissolved phosphate profile data to a depth of $3000 \mathrm{~m}$, for Transect E1 (a and d), Transect E2 (b and e) and Transect E3 (c and f). Vertical red lines (at $57.5^{\circ} \mathrm{S}$ in (a) and (d), $29.5^{\circ} \mathrm{E}$ in (b) and (e) and $30.25^{\circ} \mathrm{E}$ in $\mathbf{c}$ and $\mathbf{f}$ ) indicate the approximate position of the centre of the older and young warm-core eddies respectively and vertical blue lines (at $56^{\circ} \mathrm{S}$ in a and d) similarly indicate the position of the cold-core eddy. The horizontal red and blue bars above these vertical red lines, in turn, indicate the estimated horizontal extent of the eddies, within the $10 \mathrm{~cm}$ SSHA contour intervals.

Mesoscale features with positive SSHA values, identified from satellite altimetry, were assumed to represent anticyclonic (counterclockwise rotation) eddies (Fig. 1b). Similarly, features with negative SSHAs were assumed to be cyclonic (clockwise rotation) eddies. In the Southern Hemisphere, the centre or core of anti-cyclonic eddies is warm and sea surface height is elevated, whereas the core of cyclonic eddies is cold and characterised by negative SSHAs (Chelton, 2013). Downwelling in the core of warm-core eddies and upwelling in the core of cold-core eddies have been inferred from isopycnal displacements (Zhang et al., 2014).

Observation of the evolution of the SSHA characteristics of mesoscale features over several months suggested that intense positive SSHA values can be assumed to represent younger, more recently formed anti-cyclonic eddies (Fig. 2). Ship-based ADCP data (M. van den Berg, unpublished cruise report contribution) confirmed the direction of flow around these (Fig. 1b) mesoscale features.

On the basis of satellite SSHA images (Figs. 1b, 2), the following three main mesoscale features were identified for detailed study prior to the start of CTD transects, within the constraints of the ship time available (based on approximate eddy core positions and SSHA at time of survey, Table 1):

- a "young, warm-core" anti-cyclonic eddy at $52^{\circ} \mathrm{S}$, $30.2^{\circ} \mathrm{E}$ (core SSHA $\left.>40 \mathrm{~cm}\right)$;

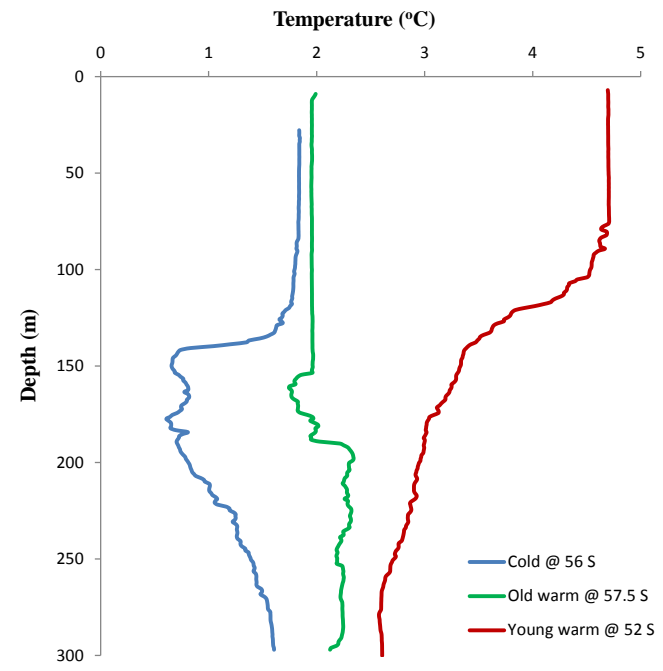

Figure 4. Upper $300 \mathrm{~m}$ water column temperature profiles from CTD stations located at the approximate cores of the three main mesoscale features present along the transect lines: in blue the coldcore eddy (CTD station E1-3 in Table 1), in green the older warmcore eddy (E1-6) and in red the young warm-core eddy (E3-3). 
Table 1. CTD station locations and identification of CTD station positions relative to eddy cores, as inferred from altimetry data. E1, E2 and E3 refer to the three transect lines shown in Fig. 1. Based on interpretation of relative SSH anomalies, E1-6 is the core of the older warm-core eddy, E1-3 that of a cold-core eddy and E3-3 that of the young warm-core eddy.

\begin{tabular}{|c|c|c|c|c|c|c|}
\hline Ship station & ID & Position relative to eddy core & Sampling date & Latitude $\left({ }^{\circ} \mathrm{S}\right)$ & Longitude $\left({ }^{\circ} \mathrm{E}\right)$ & Depth (m) \\
\hline AM00264 & E1-1 & $1^{\circ} \mathrm{N}$ of cold core & 15 April 2014 & 55.0 & 29.5 & 4506 \\
\hline AM00265 & E1-2 & $0.5^{\circ} \mathrm{N}$ of cold core & 15 April 2014 & 55.5 & 29.5 & 5296 \\
\hline AM00266 & E1-3 & Cold core & 15 April 2014 & 56.0 & 29.5 & 5581 \\
\hline AM00267 & E1-4 & $0.5^{\circ} \mathrm{S}$ of cold core & 15 April 2014 & 56.5 & 29.5 & 5288 \\
\hline AM00268 & E1-5 & $0.5^{\circ} \mathrm{N}$ of warm core & 16 April 2014 & 57.0 & 29.5 & 5275 \\
\hline AM00269 & E1-6 & Warm core & 16 April 2014 & 57.5 & 29.5 & 5565 \\
\hline AM00270 & E1-7 & $0.5^{\circ} \mathrm{S}$ of warm core & 16 April 2014 & 58.0 & 29.5 & 5261 \\
\hline AM00271 & E1-8 & $1^{\circ} \mathrm{S}$ of warm core & 16 April 2014 & 58.5 & 29.5 & 5534 \\
\hline AM00272 & E2-1 & $2.5^{\circ} \mathrm{E}$ of warm core & 17 April 2014 & 57.5 & 32.0 & 5550 \\
\hline AM00273 & E2-2 & $1.75^{\circ} \mathrm{E}$ of warm core & 18 April 2014 & 57.5 & 31.3 & 5262 \\
\hline AM00274 & E2-3 & $1^{\circ} \mathrm{E}$ of warm core & 18 April 2014 & 57.5 & 30.5 & 5270 \\
\hline AM00275 & E2-4 & $0.25^{\circ} \mathrm{E}$ of warm core & 18 April 2014 & 57.5 & 29.8 & 5269 \\
\hline AM00276 & E2-5 & $0.5^{\circ} \mathrm{W}$ of warm core & 19 April 2014 & 57.5 & 29.0 & 5268 \\
\hline AM00277 & E2-6 & $1.25^{\circ} \mathrm{W}$ of warm core & 19 April 2014 & 57.5 & 28.3 & 5135 \\
\hline AM00281 & E3-1 & $1.9^{\circ} \mathrm{W}$ of warm core & 21 April 2014 & 52.0 & 28.3 & 5481 \\
\hline AM00282 & E3-2 & $0.73^{\circ} \mathrm{W}$ of warm core & 22 April 2014 & 52.0 & 29.5 & 5379 \\
\hline AM00283 & E3-3 & Warm core & 22 April 2014 & 52.0 & 30.2 & 3817 \\
\hline AM00284 & E3-4 & $0.78^{\circ} \mathrm{E}$ of warm core & 22 April 2014 & 52.0 & 31.0 & 5154 \\
\hline
\end{tabular}

- an "older, warm-core" anti-cyclonic eddy at $57.5^{\circ} \mathrm{S}$, $29.5^{\circ} \mathrm{E}$ (core SSHA $>20 \mathrm{~cm}$ );

- a "cold-core" cyclonic eddy feature at $56^{\circ} \mathrm{S}, 29.5^{\circ} \mathrm{E}$ (core SSHA $<-20 \mathrm{~cm}$ ).

The propagation path of each of the three these eddies were tracked using archived SSHA data (Fig. 2). The results show that about 6 months before the survey cruise, the "older" warm eddy occupied a similar latitude (about $52^{\circ} \mathrm{S}$ ) than the "young" eddy sampled during the cruise. Also, the "cold-core" eddy had a similar southerly migration route and life history than the "older warm-core" eddy. It is also interesting to note that 6 months after the survey, the "young" warm eddy ended up at approximately the same latitude as that of the "older" warm eddy at the time of sampling (i.e. about $57.5^{\circ} \mathrm{S}$ ).

Based on the identification of these three mesoscale features, the following three transects (E1 to E3 in Fig. 1b) were chosen for detailed CTD profiling (station locations in Table 1) and water column sampling for chemical analysis.

- Transect E1 (15 to 16 April 2014): north-to-south transect from $55^{\circ} \mathrm{S}$ to $58.5^{\circ} \mathrm{S}$, along $29.5^{\circ} \mathrm{E}$. Eight $\mathrm{CTD}$ stations were occupied at $0.5^{\circ}$ latitude intervals; the main features along this transect were the "mature" warm-core eddy and a cold-core cyclonic eddy just north of it.

- Transect E2 (17 to 19 April 2014): east-to-west transect from $32^{\circ} \mathrm{E}$ to $28.25^{\circ} \mathrm{E}$, along $57.5^{\circ} \mathrm{S}$. Six CTD stations were occupied along this transect at $0.75^{\circ}$ longitude intervals; the main feature along this transect is the mature warm-core eddy.

- Transect E3 (21 to 22 April 2014): west-to-east transect along $52^{\circ} \mathrm{S}$, from $28.3^{\circ} \mathrm{E}$ to $31^{\circ} \mathrm{E}$. Four CTD stations were occupied along this transect at approximately $0.75^{\circ}$ longitude intervals; the main feature along this transect was the relatively young, warm-core eddy.

Along all three transects the spacing of the stations $\left(0.5^{\circ}\right.$ latitude and $0.75^{\circ}$ longitude intervals) was constrained by the available ship time and weather conditions; although higher resolution spacing would have been more ideal, the spacing is sufficient to resolve the general structure of the eddies.

\section{Seawater sampling and analysis}

Two SBE 9plus CTD systems and a moon pool CTD with a $2420 \mathrm{~L}$ Niskin bottle rosette, or alternatively a $1210 \mathrm{~L}$ Niskin bottle rosette for over-the-side deployment, were used for water column profiling and discrete water sampling at standard depths $(20,30,40,50,75,100,150,200,300$, 400, 500, 600, 700, 800, 900, 1000, 1250, 1500, 2000, 2500, $3000,4000,5000 \mathrm{~m})$. The CTD deployments along the most southerly transects (E1 and E2) were conducted with the moon pool CTD. The moon pool CTD provides more and higher volume samples but does not sample the upper $20 \mathrm{~m}$ of the water column. Unless sampling the upper $20 \mathrm{~m}$ is essential, the moon pool CTD alone is sufficient, preferable and 

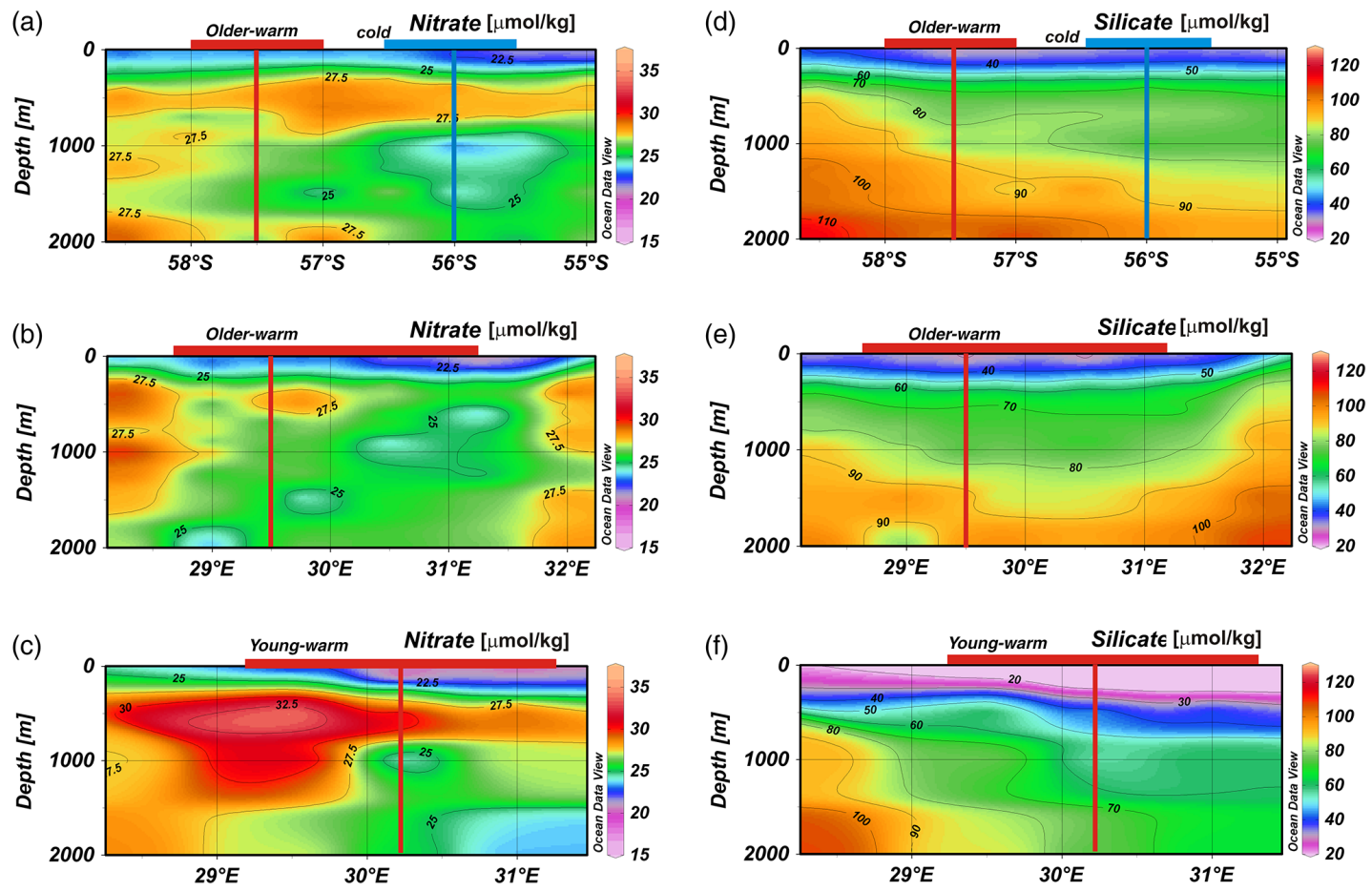

Figure 5. Dissolved nitrate and silicate profiles, plotted to a depth of $3000 \mathrm{~m}$, for Transect E1 (a and d), Transect E2 (b and e) and Transect E3 (c and f). Vertical red and blue lines represent the eddy cores as described for Fig. 3. The data available online can be used to reproduce these Ocean Dataviewer plots to shallower or deeper depths.

Table 2. Average upper ocean (surface to $100 \mathrm{~m}$ depth) physical and chemical water column characteristics, obtained from CTD profiles, in and around warm and cold eddies. Samples for nutrient and chlorophyll $a$ analysis were not collected at CTD stations E2-1 and E3-1.

\begin{tabular}{llrrrrrr}
\hline ID & $\begin{array}{l}\text { Position relative } \\
\text { to eddy core }\end{array}$ & $\begin{array}{r}T \\
\left({ }^{\circ} \mathrm{C}\right)\end{array}$ & $\begin{array}{r}S \\
(\mathrm{PSU})\end{array}$ & $\begin{array}{r}\mathrm{SiO}_{2} \\
\left.(\mu \mathrm{mol} \mathrm{kg})^{-1}\right)\end{array}$ & $\begin{array}{r}\mathrm{PO}_{4}^{3-} \\
\left.(\mu \mathrm{mol} \mathrm{kg})^{-1}\right)\end{array}$ & $\begin{array}{r}\mathrm{NO}_{3}^{-} \\
\left.(\mu \mathrm{mol} \mathrm{kg})^{-1}\right)\end{array}$ & $\begin{array}{l}\mathrm{Chl} a \\
\left(\mu \mathrm{L}^{-1}\right)\end{array}$ \\
\hline E1-1 & $1^{\circ} \mathrm{N}$ of cold core & 2.31 & 33.97 & 29.9 & 1.50 & 20.9 & 0.14 \\
$\mathrm{E} 1-2$ & $0.5^{\circ} \mathrm{N}$ of cold core & 1.75 & 33.98 & 29.6 & 1.37 & 20.4 & 0.33 \\
$\mathrm{E} 1-3$ & Cold core & 1.83 & 33.98 & 30.8 & 1.47 & 21.6 & 0.35 \\
$\mathrm{E} 1-4$ & $0.5^{\circ} \mathrm{S}$ of cold core & 1.99 & 33.95 & 29.3 & 1.58 & 23.6 & 0.36 \\
$\mathrm{E} 1-5$ & $0.5^{\circ} \mathrm{N}$ of warm core & 1.77 & 33.96 & 27.6 & 1.53 & 22.7 & 0.58 \\
$\mathrm{E} 1-6$ & Warm core & 1.96 & 33.98 & 25.7 & 1.56 & 22.7 & 0.57 \\
$\mathrm{E} 1-7$ & $0.5^{\circ} \mathrm{S}$ of warm core & 0.88 & 33.87 & 34.8 & 1.56 & 23.3 & 0.31 \\
$\mathrm{E} 1-8$ & $1^{\circ} \mathrm{S}$ of warm core & 1.04 & 33.93 & 35.2 & 1.51 & 22.3 & 0.23 \\
\hline $\mathrm{E} 2-1$ & $2.5^{\circ} \mathrm{E}$ of warm core & 1.09 & 33.92 & & & & \\
$\mathrm{E} 2-2$ & $1.75^{\circ} \mathrm{E}$ of warm core & 1.27 & 33.99 & 31.2 & 1.46 & 20.1 & 0.44 \\
$\mathrm{E} 2-3$ & $1^{\circ} \mathrm{E}$ of warm core & 1.71 & 33.96 & 26.2 & 1.51 & 21.5 & 0.49 \\
$\mathrm{E} 2-4$ & $0.25^{\circ} \mathrm{E}$ of warm core & 1.62 & 33.97 & 29.0 & 1.56 & 22.5 & 0.33 \\
$\mathrm{E} 2-5$ & $0.5^{\circ} \mathrm{W}$ of warm core & 1.60 & 33.96 & 29.7 & 1.60 & 22.7 & 0.44 \\
$\mathrm{E2}-6$ & $1.25^{\circ} \mathrm{W}$ of warm core & 1.60 & 33.98 & 29.1 & 1.49 & 22.4 & 0.42 \\
\hline $\mathrm{E} 3-1$ & $1.9^{\circ} \mathrm{W}$ of warm core & 1.69 & 34.04 & & & & \\
$\mathrm{E} 3-2$ & $0.73^{\circ} \mathrm{W}$ of warm core & 3.45 & 33.80 & 13.7 & 1.39 & 21.9 & 0.24 \\
$\mathrm{E} 3-3$ & Warm core & 4.70 & 33.77 & 4.4 & 1.34 & 20.2 & 0.18 \\
$\mathrm{E} 3-4$ & $0.78^{\circ} \mathrm{E}$ of warm core & 4.76 & 33.77 & 3.5 & 1.34 & 19.5 & 0.18 \\
\hline
\end{tabular}


often the only option in extremely rough seas. If time and conditions allow, both CTDs can be deployed, in sequence, to maximise sampling resolution. The moon pool CTD was lost after completion of transects E1 and E2 as a result of damage sustained in very rough seas, and transect E3 was carried out with the smaller CTD only. The CTD temperature sensors were calibrated before and after the cruise to ensure accuracy and achievement of the manufacturer's stated measurement precision of $\pm 0.0001{ }^{\circ} \mathrm{C}$. Salinity was computed from CTD data in practical salinity units (PSU) and the conductivity sensor calibrated using a combination of international standards and discrete samples, for every CTD cast, with the salinometer's stated measurement precision \pm 0.0001 PSU. The CTD oxygen sensor was calibrated with oxygen measurements obtained from discrete samples at selected depths for each CTD cast, applying the Winkler titration method using an electronic stand (Hansen, 1999). The precision of the oxygen titration was $\pm 0.45 \mu \mathrm{mol} \mathrm{kg}{ }^{-1}$. Turbidity, given in nephelometric turbidity units, was measured with a sensor connected to the CTD system, using the original calibration provided by the manufacturer.

Seawater samples for chemical analyses were collected from the Niskin bottles at the standard depths detailed earlier. Samples for dissolved oxygen analysis were collected from the Niskin bottles via silicone tubing, taking care not to introduce or trap air bubbles. For dissolved inorganic nutrient analysis, acid-washed $15 \mathrm{~mL}$ polypropylene tubes were thoroughly rinsed with sample water before filling and frozen at $-80^{\circ} \mathrm{C}$ prior to ship-based analysis using an Astoria AutoAnalyser Series 300, expanded to four channels. Dissolved nitrate $\left(\mathrm{NO}_{3}^{-}\right)$, nitrite $\left(\mathrm{NO}_{2}^{-}\right)$and silicate $\left(\mathrm{SiO}_{2}\right)$ were determined following the methods of Armstrong et al. (1967) and phosphate $\left(\mathrm{PO}_{4}^{3-}\right)$ according to the methods of Bernhardt and Wilhelms (1967), with typical in-run precision of $\pm 0.1 \mu \mathrm{mol} \mathrm{L}-1$ for $\mathrm{NO}_{3}^{-}$and $\mathrm{NO}_{2}^{-}, \pm 0.02 \mu \mathrm{mol} \mathrm{L}^{-1}$ for $\mathrm{PO}_{4}^{3-}$ and $\pm 0.24 \mu \mathrm{mol} \mathrm{L}{ }^{-1}$ for $\mathrm{SiO}_{2}$.

Samples for chlorophyll $a$ analysis were taken at four depths (near-surface, above the fluorescence maximum ( $F$ $\max$ ), at $F$-max and below the $F$-max), with the depth of $F$-max established from the downcast, continuous CTD fluorescence profile. Seawater samples $(200 \mathrm{~mL})$ for chlorophyll $a$ analysis were collected in pre-rinsed plastic bottles. Samples were immediately filtered, under vacuum onto $25 \mathrm{~mm}$ Whatman ${ }^{\mathrm{TM}} \mathrm{GF} / \mathrm{F}$ glass fibre filter papers (Parsons et al., 1984). The filter papers were frozen in aluminium foil pouches for storage until analysis. Chlorophyll $a$ was measured fluorometrically on a Turner Designs 10-AU fluorometer after extraction in $90 \%$ acetone (Welschmeyer and Waterhouse, 1995), with a precision of approximately $5 \%$. The fluorometer was calibrated with chlorophyll $a$ standard (Sigma Chemical Co., USA) in $90 \%$ acetone solution with a GBC Cintra 404 spectrophotometer and an extraction coefficient of $87.67 \mathrm{Lg}^{-1} \mathrm{~cm}^{-1}$.
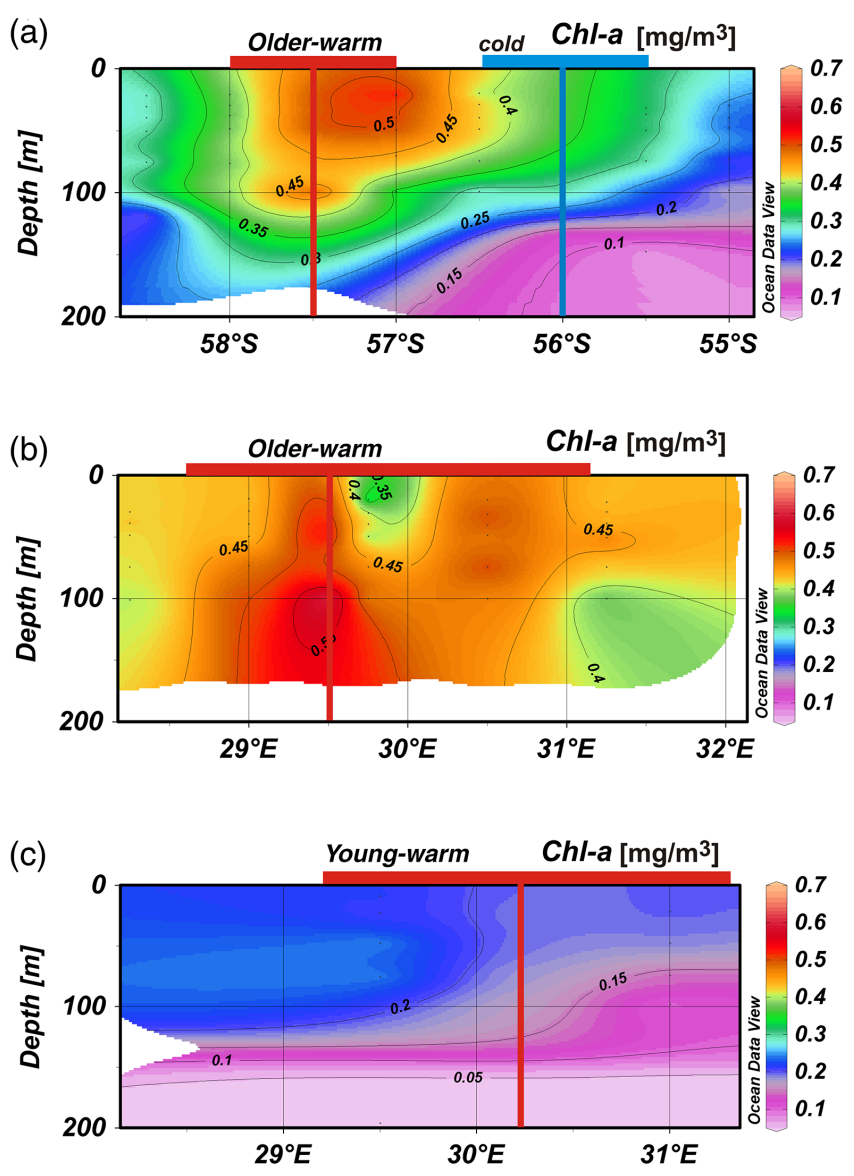

Figure 6. Chlorophyll $a$ profiles, plotted to a depth of $200 \mathrm{~m}$, for Transect E1 (a and d), Transect E2 (b and e) and Transect E3 (c and f). Vertical red and blue lines represent the eddy cores as described for Fig. 3. The data available online can be used to reproduce these Ocean Dataviewer plots to shallower or deeper depths.

\section{Data overview and discussion}

In situ CTD profiling data (Figs. 3a, b, c and 4) confirmed the presence and position of the anti-cyclonic and cyclonic eddies, targeted for this study based on SSHA observational data (Fig. 1). The average values of physical and chemical parameters for the upper $100 \mathrm{~m}$ of the water column is summarised for all CTD stations in Table 2 and profile data for temperature, salinity, nutrients and chlorophyll $a$ are shown in Figs. 3, 5 and 6. These data demonstrate a number of significant differences between the eddies, most notably

- the old, warm (or anti-cyclonic) eddy at $57.5^{\circ} \mathrm{S}$ (Table 1) has a maximum core temperature of 2.2 to $2.35^{\circ} \mathrm{C}$, which is observed in the 200 to $300 \mathrm{~m}$ depth range (Fig. 4). In the core of the cold-core eddy located $1.5^{\circ}$ north of the core of the older warm-core feature, the temperature reaches a value of almost $1.85^{\circ} \mathrm{C}$ in the upper $100 \mathrm{~m}$ of the water column. The young, warm-core eddy much further north at $52^{\circ} \mathrm{S}$, in contrast, is char- 
acterised by core temperatures of around $4.7^{\circ} \mathrm{C}$ in the well-mixed upper $100 \mathrm{~m}$ layer and around 3 to $2.6^{\circ} \mathrm{C}$ in the 200 to $300 \mathrm{~m}$ depth range. The sampling survey, therefore, successfully captured the different temperature characteristics of cyclonic and anti-cyclonic eddies at different stages in their maturity.

- In the upper $100 \mathrm{~m}$, the young warm-core eddy is $2.74{ }^{\circ} \mathrm{C}$ warmer, less saline by $0.21 \mathrm{PSU}$, with silicate levels $\sim 80 \%$ lower and chlorophyll $a$ levels more than a factor of 2 lower than those in its older warm-core equivalent further south eddy at the time of sampling (i.e. about $57.5^{\circ} \mathrm{S}$ ).

- In contrast, the upper ocean water characteristics of the cold-core and older warm-core eddies, at 56 and $57.5^{\circ} \mathrm{S}$ respectively, are much more similar to each other than is the case for the younger versus older warmcore eddies (Table 2). The cold eddy is, on average, only $0.13{ }^{\circ} \mathrm{C}$ colder than the older warm-core eddy, with approximately the same upper ocean salinity values. The older warm-core eddy has slightly higher upper ocean phosphate and nitrate concentrations than the cold-core eddy, 6 and $5 \%$ respectively, but has significantly higher chlorophyll- $a(+63 \%)$ and lower silicate levels $(-17 \%)$.

The data show that the most notable differences between the young and older warm-core eddies are their surface ocean dissolved silicate and chlorophyll $a$ characteristics. One possible explanation is that, as warm-core eddies migrate in a southerly direction (Fig. 2), lateral and/or vertical mixing with adjacent silicate-rich water masses results in increasing surface silicate levels. These higher silicate levels, together with potential additional controls such as light and iron availability, then results in dramatically increased levels of productivity. Bongo net tows conducted during the survey (unpublished results), confirmed that the increased levels of chlorophyll $a$, south of the polar front, are associated with diatom productivity. Alternatively, if it is more appropriate to think of eddies as local (but persistent) perturbations in the density structure, then higher silicate values in the older, warm-core eddy are simply consistent with the characteristics of water masses south of the polar front compared to further north.

In summary, the in situ nutrient and chlorophyll $a$ profile data presented here provide valuable input data for the modelling of the complex biogeochemical processes associated with mesoscale activity in the Southern Ocean.

Author contributions. S. de Villiers determined the sampling strategy, collected samples and oversaw and collated the measurements; K. Siswana and K. Vena assisted in sample collection, chemical analysis and data presentation; S. de Villiers prepared the manuscript.
Acknowledgements. All ship-based participants, crew and research staff, in some way or another, contributed to the collection of this data set, and their contributions are gratefully acknowledged. The Chief Scientist for the cruise was H. Verheye, and the cruise and associated research activities were financed by the Department of Environmental Affairs.

Edited by: R. Key

\section{References}

Ansorge, I. J., Pakhomov, E. A., Kaehler, S., Lutjeharms, J. R. E., and Durgadoo, J. V.: Physical and biological coupling in eddies in the lee of the South-West Indian Ridge, Polar Biol., 33, 747 759, 2010.

Ansorge, I. J., Jackson, J. M., Reid, K., Durgadoo, J. V., Swart, S., and Eberenz, S.: Evidence of a southward eddy corridor in the South-West Indian ocean, Deep-Sea Res. II, 119, 69-76, 2015.

Armstrong, F. A. J., Stearns, C. A., and Strickland, J. D. H.: The measurement of upwelling and subsequent biological processes by means of the Technicon Autoanalyzer and associated equipment, Deep-Sea Res., 14, 381-389, 1967.

Bernhardt, H. and Wilhelms, A.: The continuous determination of low level iron, soluble phosphate and total phosphate with the AutoAnalyzer, Technicon Symposia I, 385-389, 1967.

Chelton, D.: Mesoscale eddy effects, Nat. Geosci., 6, 594-594, 2013.

Chelton, D. B., Gaube, P., Schlax, M. G., Early, J. J., and Samelson, R. M.: The influence of nonlinear mesoscale eddies on nearsurface oceanic chlorophyll, Science, 334, 328-332, 2011.

Chen, Y. L., Chen, H.-Y., Jan, S., Lin, Y.-H., Kuo, T.-H., and Hung, J.-J.: Biologically active warm-core anticyclonic eddies in the marginal seas of the western Pacific Ocean, Deep Sea Res. Pt. I, 106, 68-84, 2015.

Dong, S., Sprintall, J., and Gille, S. T.: Location of the Antarctic Polar Front from AMSR-E satellite sea surface temperature measurements, J. Phys. Ocean., 36, 2075-2089, 2006.

Durgadoo, J. V., Ansorge, I. J., de Cuevas, B. A., Lutjeharms, J. R. E., and Coward, A. C.: Decay of eddies at the South-West Indian Ridge, S. Afr. J. Sci., 107, 673, doi:10.4102/sajs.v107i11/12.673, 2011.

Falkowski, P., Ziemann, D., Kolber, Z., and Bienfang, P.: Role of eddy pumping in enhancing primary production in the ocean, Nature, 352, 55-58, 1991.

Ferrari, R. and Wunch, C.: Ocean circulation kinetic energy: reservoirs, sources, and sinks, Ann. Rev. Fluid Mech., 41, 253-282, 2009.

Frenger, I., Gruber, N., Knutti, R., and Münnich, M.: Imprint of Southern Ocean eddies on winds, clouds and rainfall, Nat. Geosci., 6, 608-612, 2013.

Fu, L.-L., Chelton, D. B., Le, P.-Y., and Morrow, R.: Eddy dynamics from satellite altimetry, Oceanography, 23, 14-25, 2010.

Gouretski, V. V. and Danilov, A. I.: Characteristic of warm rings in the African sector of the Antarctic Circumpolar current, DeepSea Res., 41, 1131-1157, 1994.

Hansen, H. P.: Determination of oxygen, in: Methods of Seawater analysis, edited by: Grasshoff, K. K. and Ehrhardt, M., WileyVCH, Weinheim, 75-89, 1999. 
Joyce, T. M., Patterson, S. L., and Millard Jr., R. C.: Anatomy of a cyclonic ring in the Drake Passage, Deep-Sea Res., 28, 12651287, 1981.

Klein, P. and Lapeyre, G.: The oceanic vertical pump induced by mesoscale and submesoscale turbulence, Ann. Rev. Mar. Sci., 1, 351-375, 2009.

Lehahn, Y., d'Ovidio, F., Lévy, M., Amitai, Y., and Heifetz, E.: Long range transport of a quasi isolated chlorophyll patch by an Agulhas ring, Geophys. Res. Lett., 38, L16610, doi:10.1029/2011GL048588, 2011.

Lévy, M., Klein, P., and Treguier, A.-M.: Impact of sub-mesoscale physics on production and subduction of phytoplankton in an oligotrophic regime, J. Mar. Res., 59, 535-565, 2001.

Mahadevan, A. and Archer, D.: Modeling the impact of fronts and mesoscale circulation on the nutrient supply and biogeochemistry of the upper ocean, J. Geophys. Res., 105, 1209-1225, 2000.

McGillicuddy Jr., D. J., Anderson, L. A., Bates, N. R., Bibby, T., Buesseler, K. O., Carlson, C. A., Davis, C. S., Ewart, C., Falkowski, P. G., Goldtwait, S. A., Hansell, D. A., Jenkins, W. J., Johnson, R., Kosnyrev, V. K., Ledwell, J. R., Li, Q. P., Siegel, D. A., and Steinberg, D. K.: Eddy/wind interactions stimulate extraordinary mid-ocean plankton blooms, Science, 316, 10211026, 2007.

Morrow, R. A., Coleman, R., Church, J. A., and Chelton, D. B.: Surface eddy momentum flux and velocity variance in the Southern Ocean from GEOSAT altimetry, J. Phys. Ocean., 24, 2050-2071, 1994.
Parsons, T. R., Maita, Y., and Lalli, C. M.: A Manual of Chemical and Biological Methods for Seawater Analysis, Pergamon Press, Oxford, 173 pp., 1984.

Pollard, R. T. and Read, J. F.: Circulation pathways and transports of the Southern Ocean in the vicinity of the Southwest Indian Ridge, J. Geophys. Res., 106, 2881-2898, doi:10.1029/2000JC900090, 2001.

Sheen, K. L., Garabato, A. C. N., Brearley, J. A., Meredith, M. P., Polzin, K. L., Smeed, D. A., Forryan, A., King, B. A., Sallee, J.-B., St. Laurent, L., Thurnherr, A. M., Toole, J. M., Waterman, S. N., and Watson, A. J.: Eddy-induced variability in Southern Ocean abyssal mixing on climatic timescales, Nat. Geosci., 7, 577-582, 2014.

Siegel, D., Peterson, P., McGillicuddy, D., Maritorena, S., and Nelson, N.: Bio-optical footprints created by mesoscale eddies in the Sargasso Sea, Geophys. Res. Lett., 38, L13608, doi:10.1029/2011GL047660, 2011.

Stramma, L., Bange, H. W., Czeschel, R., Lorenzo, A., and Frank, M.: On the role of mesoscale eddies for the biological productivity and biogeochemistry in the eastern tropical Pacific Ocean off Peru, Biogeosciences, 10, 7293-7306, doi:10.5194/bg-10-72932013, 2013.

Welschmeyer, N. A. and Waterhouse, T. Y.: Taxon-specific analysis of microzooplankton grazing rates and phytoplankton growth rates, Limnol. Oceanogr., 40, 827-834, 1995.

Zhang, Z., Wang, W., and Qui, B.: Oceanic mass transport by mesoscale eddies, Science, 345, 322-324, 2014. 